\title{
The Benefits of Local Cross-Sector Consumer Ownership Models for the Transition to a Renewable Smart Energy System in Denmark. An Exploratory Study
}

\author{
Leire Gorroño-Albizu
}

Aalborg University, Department of Planning, Rendsburggade 14, 9000 Aalborg, Denmark; lga@plan.aau.dk

Received: 14 February 2020; Accepted: 19 March 2020; Published: 22 March 2020

\begin{abstract}
Smart energy systems (SESs), with integrated energy sectors, provide several advantages over single-sector approaches for the development of renewable energy systems. However, cross-sector integration is at an early stage even in areas challenged by the existing high shares of variable renewable energy (VRE). The promotion of cross-sector integration requires institutional incentives and new forms of actor participation and interaction that are suitable to address the organisational challenges of implementing and operating SESs. Taking as the point of departure an empirical case and its institutional context, this article presents an exploratory study of the ability of cross-sector consumer ownership at different locations in the power distribution system to address those challenges in Denmark. The methods comprise interviews of relevant stakeholders and a literature review. The results indicate that distant and local cross-sector integration will be necessary to reduce overinvestments in the grid and that consumer co-ownership of wind turbines and power-to-heat $(\mathrm{P} 2 \mathrm{H})$ units in district heating $(\mathrm{DH})$ systems may provide advantages over common separate ownership with regard to local acceptance and attractiveness of investments. Several possibilities are identified to improve the current institutional incentive system in Denmark. Finally, the results suggest the relevance of analysing the possibility for single-sector energy companies to transition to smart energy companies.
\end{abstract}

Keywords: smart energy system; renewable energy system; sector integration; consumer ownership; local ownership; prosumer; organisational innovation

\section{Introduction}

A drastic reduction in global $\mathrm{CO}_{2}$ emissions is crucial to mitigate global warming and its devastating consequences [1]. Therefore, the EU has set the target to reduce its greenhouse gas emissions by $80-95 \%$ compared to 1990 by 2050 [2]. Achieving this target requires the substitution of fossil fuels, with significant reductions in energy demand and a high penetration of VRE [2]. This implies fundamental changes in the energy system - most remarkably, the significant loss of flexibility on the production side (previously provided by easily and cheaply storable fossil fuels) and the decentralisation of the energy system (in order to harvest local energy resources with modular/scalable technologies such as wind turbines and solar panels). These changes are not only of a technical nature as they are expected to demand and open up important organisational changes, including new business models and the possible reconfiguration of the energy system's ownership [3-5]. Furthermore, the new EU Renewable Energy Directive and Electricity Market Directive, which include definitions for "renewable energy communities" and "citizen energy communities", respectively, could also foster ownership changes by promoting the implementation of renewable energy projects with open and participatory forms of citizen ownership in the EU Member States. 
As the implementation of VRE progresses, these technologies are facing greater local opposition [6], lower market prices due to the merit-order-effect, and curtailment due to electricity grid congestion [7]. Several studies conclude that these organisational challenges could be addressed with cross-sector integration (i.e., by integrating the electricity, heating and cooling $(\mathrm{H} \& \mathrm{C})$, and transport sectors) $[8,9]$ and local inclusive ownership models [10], such as local consumer cooperatives or local municipal companies [11]. However, the institutional incentive system does not yet promote these solutions to the levels that are necessary to address the above mentioned challenges and to implement a renewable SES [12], not even in countries and local regions already pressed by the high shares of VRE, e.g., Denmark.

Denmark is a frontrunner in wind turbine implementation-wind turbines supplied $46.7 \%$ of the final electricity demand in 2019 [13]. Moreover, about $64 \%$ of the households in the country are connected to DH systems [14]. However, only $1.1 \%$ of the heat demand in DH systems was supplied by heat pumps (HPs) in 2018 [14], which indicates a very low integration of the electricity and H\&C sectors, in spite of the existing high potential for it. Denmark is also well known for its significant levels of local and inclusive ownership of the energy system [11,15]. Nevertheless, since the second half of the 1990s there has been a trend for exclusive and distant ownership of wind turbines, which is one of the reasons for the observed increase of local opposition to them $[6,11]$.

The country has the target to reduce its greenhouse gas emissions by $70 \%$ by 2030 and to become fossil fuel-free by 2050. The achievement of these ambitious targets requires the improvement of the Danish institutional incentive system and possibly new forms of local and inclusive ownership in order to address the mentioned organisational challenges and foster the implementation of a SES [12]. The current Danish institutional incentives do not differentiate between nearby or distant cross-sector integration [12]. This is seen as problematic given that cross-sector integration is expected to reduce electricity grid costs by reducing congestion issues [8,16], which have a strong locational character [7]. Moreover, the current electricity spot market structure makes it necessary for wind investors to access support schemes or arrange beneficial power-purchase-agreements (PPAs) in order to make wind projects economically attractive [17]. In this respect, the abolition of the feed-in tariff scheme and the introduction of the tender scheme considerably reduces the possibility for wind projects with local inclusive ownership to have access to support schemes and favours large commercial wind investors instead [18,19]. Furthermore, the current institutional incentive system completely fails to promote local acceptance of wind turbines in Denmark-proven by the fact that 305 MW of wind capacity was cancelled in 2017 in the country because of protests [20].

In such a changing and hostile environment, local and inclusive ownership of wind turbines continues to develop in Denmark through innovative forms such as local cross-sector consumer ownership, e.g., in Hvide Sande, where the local DH company has bought the local wind turbines [11]. Hvelplund et al. [12] suggest that such cross-sector consumer ownership models might be advantageous to address the organisational challenges of implementing SESs [12]. However, the idea has not been empirically studied yet and that is what the study presented in this article intends to do.

Taking as a point of departure the case of Hvide Sande, this article presents an exploratory analysis that answers the following research questions:

1. What is the (theoretical) ability of cross-sector consumer ownership at different locations to address the organisational challenges of SESs in Denmark?

2. How does the current Danish institutional incentive system encourage/discourage cross-sector consumer ownership at different locations in the power distribution system?

3. Based on 1 and 2, how could the Danish institutional incentive system be improved to better address the organisational challenges of SESs?

4. What issues regarding ownership and SESs can be identified for further research? 
Section 2 presents the theoretical approach and methodology of the study. Section 3 is divided into four sub-sections, which answer research questions 1-4, respectively. Finally, Section 4 discusses the results of the study.

\section{Theoretical Approach and Methods}

\subsection{SESs and their Interrelations}

SESs are renewable energy systems that comprise smart electricity, thermal and gas grids and are characterised by integrated electricity, $\mathrm{H} \& \mathrm{C}$, and transport sectors [16]. Figure 1 presents the interrelations between the implementation and operation of the SES, the incentive system, the political system/process, the available resources, and the cognitive/cultural characteristics. The diagram is an adaptation of those presented by Hvelplund et al. [12] and Gorroño-Albizu et al. [11]. The differentiation of "the technical system" and the "actor participation and interaction" presented in Figure 1 intends to emphasise the need to better understand potential organisational possibilities (including different ownership models) for SESs as well as their interrelation with the technical system and the institutional incentive system. Figure 1 suggests that the characteristics of the technical system could influence which/how actors participate in the implementation and operation of the energy system. Thus, different types of actor participation and interactions could be expected, e.g., for centralised and decentralised energy systems. At the same time, the figure suggests that different actor participation and interactions could lead to implementation and operation of the technical energy system in a different way. In this sense, different implementation and operation behaviours could be expected for VRE and P2H in DH systems, e.g., when being owned by different companies belonging to different sectors (which is currently the norm) or by one single (cross-sector) company (i.e., when being regarded as one single system). This understanding motivates the analysis of the co-ownership of wind turbines and $\mathrm{P} 2 \mathrm{H}$ by DH companies presented in this article. Such co-ownership represents a cross-sector ownership model. Finally, Figure 1 suggests that, in order to understand the implementation and operation of SESs, it is important to comprehend how the incentive system influences both the technical system and the actor participation and interaction [11].

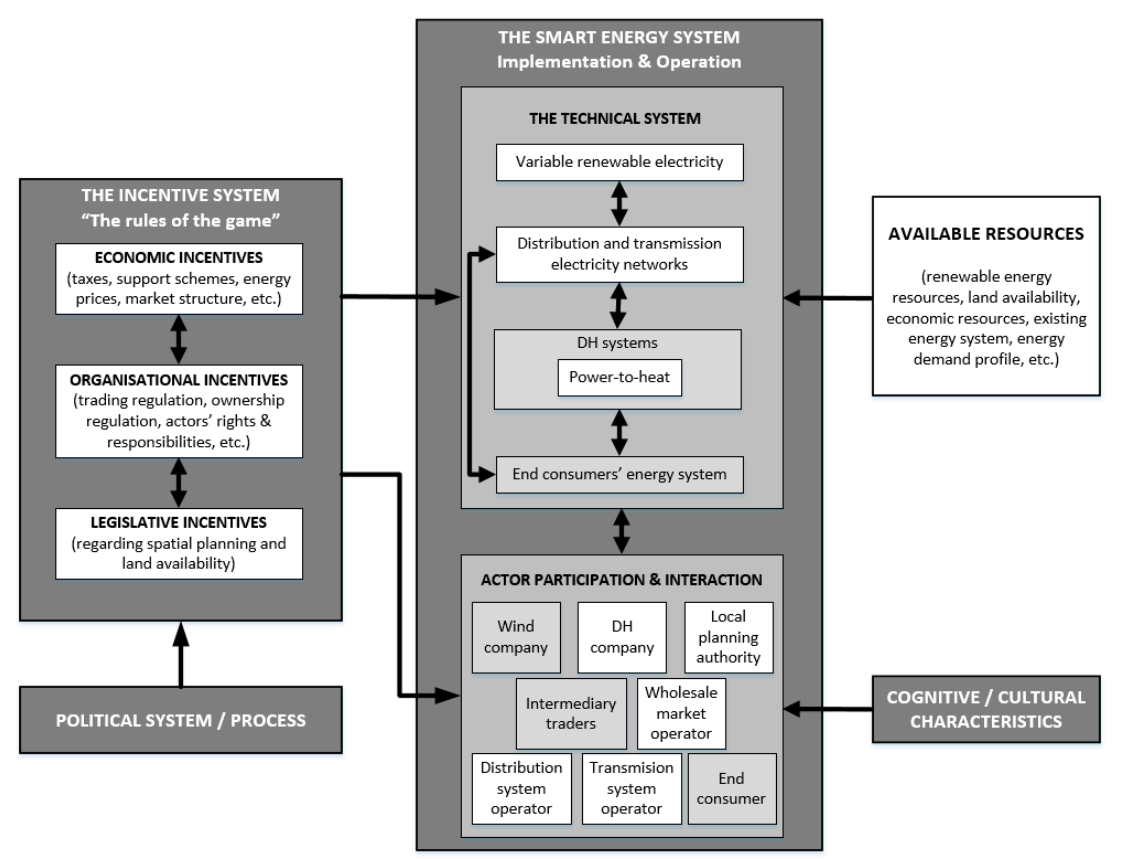

Figure 1. The theoretical approach of the study, inspired by [12] and [11]. The white boxes in the diagram present the elements of SESs included in the scope of the study. The interactions between the actors are not drawn because questioning and analysing those interactions is one of the objectives of the study. DH: district heating. 
Figure 1 also presents the delimitations of the study. The study focuses on VRE infrastructure (particularly wind turbines), the electricity grid, and $\mathrm{P} 2 \mathrm{H}$ in $\mathrm{DH}$ systems. Individual heating systems and other forms of cross-sector integration as well as the end consumers' energy system are outside of the scope. The study analyses the present "rules of the game" but not the political process behind these rules or the end consumers' political influence. However, the study indirectly considers the end consumer through the consumer-owned DH companies and the local community through the local planning authority. Finally, the cognitive/cultural characteristics that have influenced the actor participation and interaction and the dominance of consumer-owned DH companies in Denmark are outside of the scope. The delimitations of the study are defined in line with the problem formulation and the research questions presented in the introduction.

\subsection{The Organisational Challenges of SESs, Ownership and Location}

The organisational challenges considered in this study are: (1) reduction of overinvestments in the electricity grid, (2) enhancement of local acceptance of wind turbines, and (3) improvement of the economy of wind turbines and $\mathrm{P} 2 \mathrm{H}$ in DH systems. In the following it is explained how these three challenges are related to the ownership of the technical SES based on existing literature. Furthermore, the relevance of the location aspect, already mentioned in the introduction, is highlighted. These knowledge forms the theoretical background to answer the research questions.

\subsubsection{Reduction of Overinvestments in the Electricity Grid}

Increasing flexible demand through cross-sector integration may reduce the need for expanding and reinforcing the electricity transmission grid in order to integrate high shares of VRE [8]. This requires that investments (in VRE, $\mathrm{P} 2 \mathrm{H}$ in DH systems and the electricity grid) and operations (of VRE and $\mathrm{P} 2 \mathrm{H}$ units) are coordinated with regard to three key aspects: time, size, and location.

The complexity of the necessary coordination to minimise the overall system costs arises from the multiple actors, interests, and institutional incentives that intervene in investment and operations' decision-making, as indicated in Figure 1. Based on a preliminary analysis made for Denmark, Hvelplund and Djørup [3] suggest that local consumer ownership of SESs would facilitate the necessary coordination. In line with that idea, Gill et al. [21] argue that co-ownership is the easiest solution for local coupling of wind power generation and local demand with the purpose of avoiding wind power curtailment due to grid congestions. Moreover, the analysis carried out by Gill et al. indicates that co-ownership reduces the transaction costs of local balancing. The main reason behind those authors' arguments is that, in a co-ownership configuration, there is only one decision-maker for the investments in and operations of the wind turbines, the $\mathrm{P} 2 \mathrm{H}$ units, and the rest of the components of the DH system (e.g., thermal storage, solar collectors, combined heat and power (CHP) plants, etc.), which are regarded as parts of the same system [22]. This facilitates the coordination.

\subsubsection{Local Opposition to Wind Turbines}

Local opposition to wind turbines is a well-documented phenomenon that has caused delays and cancellation of projects. Similar public reactions towards other VRE technologies could be expected as their implementation increases. Reducing the need for wind capacity through, e.g., efficiency measures would result in lower conflicts. Nonetheless, addressing possible local conflicts and enhancing local support is essential. To this end, participatory planning processes and a fair distribution of local impacts and benefits are recommended [23]. In this respect, local and inclusive citizen ownership has proven to be an effective solution [10] as it confers the local community the control over the decisions on the wind turbine project and ensures broad distribution of benefits between the members of the local community. Gorroño-Albizu et al. [11] provide examples of local and inclusive citizen ownership, which include, e.g., local consumer cooperatives and local municipal companies. 


\subsubsection{Attractiveness of Investments in VRE and P2H in DH Systems}

The levelised cost of wind power has decreased significantly in the past decades, reaching similar or even lower levelised costs per MWh than those of fossil fuel technologies [24]. However, the merit order effect and curtailment because of grid congestion reduce the profitability of wind investments as increasing volumes of wind power enter in the electricity system. Increasing flexible demand through cross-sector integration (e.g., $\mathrm{P} 2 \mathrm{H}$ ) has been presented as a solution to raise wind energy utilisation and, in this way, improve wind economy $[9,12]$. Therefore, the co-ownership of wind turbines and flexible demand (e.g., $\mathrm{P} 2 \mathrm{H}$ in DH systems) could improve the economy of wind turbines-as long as both are located within the same electricity grid congestion node [21].

Some studies have investigated the role of ownership in the attractiveness of investments in wind turbines (see e.g., [25,26]) and in DH systems (see e.g., [27]). The differences in attractiveness of investments is to some extent related to the fact that different types of investors seek different levels of profitability and investment time horizons. The think-tank Grøn Energi [28] argues that shorter or longer time horizons and higher or lower expectations for returns in investments have important implications for the investment choices and future competitiveness of DH systems. In this regard, according to Grøn Energi, long time horizons-which are often preferred by consumer and public investors rather than by commercial investors-will be extremely important to ensure the adoption of more sustainable and flexible technologies (including solar collectors, thermal storage, and HPs). This could imply that wind turbines might also be attractive for consumer-owned DH companies (with P2H units) who seek for long-term return in investments.

\subsubsection{SESs, Cross-sector Ownership and Different Location Cases}

From the above explanations it may be concluded that the location of the technical system's components and the ownership influence the ability to address the organisational challenges presented in this study. Therefore, this study analyses the co-ownership of wind turbines and $\mathrm{P} 2 \mathrm{H}$ by DH companies implemented at different location cases. These are (1) distant, (2) local, and (3) behind-the-meter cross-sector integration, as presented in Figure 2. The location cases should not be regarded as either/or alternatives as they already co-exist and will probably still do so in the future. Nevertheless, they are differentiated in order to assess their influence in the ability of the co-ownership solution to address the organisational challenges of SESs.

\subsection{Methodology}

Semi-structured interviews and literature review are used to answer the research questions of the study. The interviews were conducted mainly with the stakeholders forming the institutional context in which the case of Hvide Sande is embedded in line with the theoretical approach presented in Figure 1. To the best knowledge of the author, Hvide Sande DH is the only DH company in Denmark that owns wind turbines. Therefore, the input from the stakeholders involved in this case is expected to provide insights about the co-ownership model that other stakeholders might not hold. Moreover, the expertise of Ringkøbing DH, who has explored and discarded the possibility of implementing the co-ownership solution, is also collected. Additionally, a DH consultant has been interviewed to deepen the understanding about the operation of DH systems. Table 1 lists the interviewed stakeholders. Written transcripts were compiled for the interviews.

The objective of the interviews is to understand the (theoretical) ability of the co-ownership model, how the technical system and institutional context are influenced by different ownership models, and how the incentive system encourages/discourages different ownership models. The specific experiences by Hvide Sande DH are out of the scope of the study as they do not answer the research questions. The interviews had different focuses, related to the expertise of the interviewed stakeholder. The questions for grid operators were targeted at understanding the challenges of implementing higher shares of VRE and electrifying the H\&C sector as well as the benefits that different cross-sector 
integration cases, presented in Figure 2, could provide for solving the expected electricity grid issues. The questions for DH companies and the DH consultant were targeted at understanding the operation of the DH system (with and without wind turbines), the economic attractiveness of investing in wind turbines for a DH company under the current institutional incentive system, and the possibility of obtaining local acceptance of wind turbines. Finally, the questions for the local planning authority were targeted at understanding the local energy system and the interactions between the local stakeholders. The interviews also made it possible to capture different opinions on the advantages and disadvantages offered by the different cross-sector integration cases and the consumer cross-sector ownership model under analysis in this study. These opinions are presented as part of the analysis in the results section.

The list of interviewed stakeholders is small and therefore only a limited understanding about stakeholders' expectations regarding cross-sector integration and cross-sector ownership and about relevant research lines regarding ownership and SESs are captured. Nevertheless, this exploratory study advances the existing knowledge about the suitability of institutional incentives and ownership models for SESs and is expected to build a stronger knowledge basis for further research on the topic.

\section{CASES OF CROSS-SECTOR INTEGRATION OF VRE}
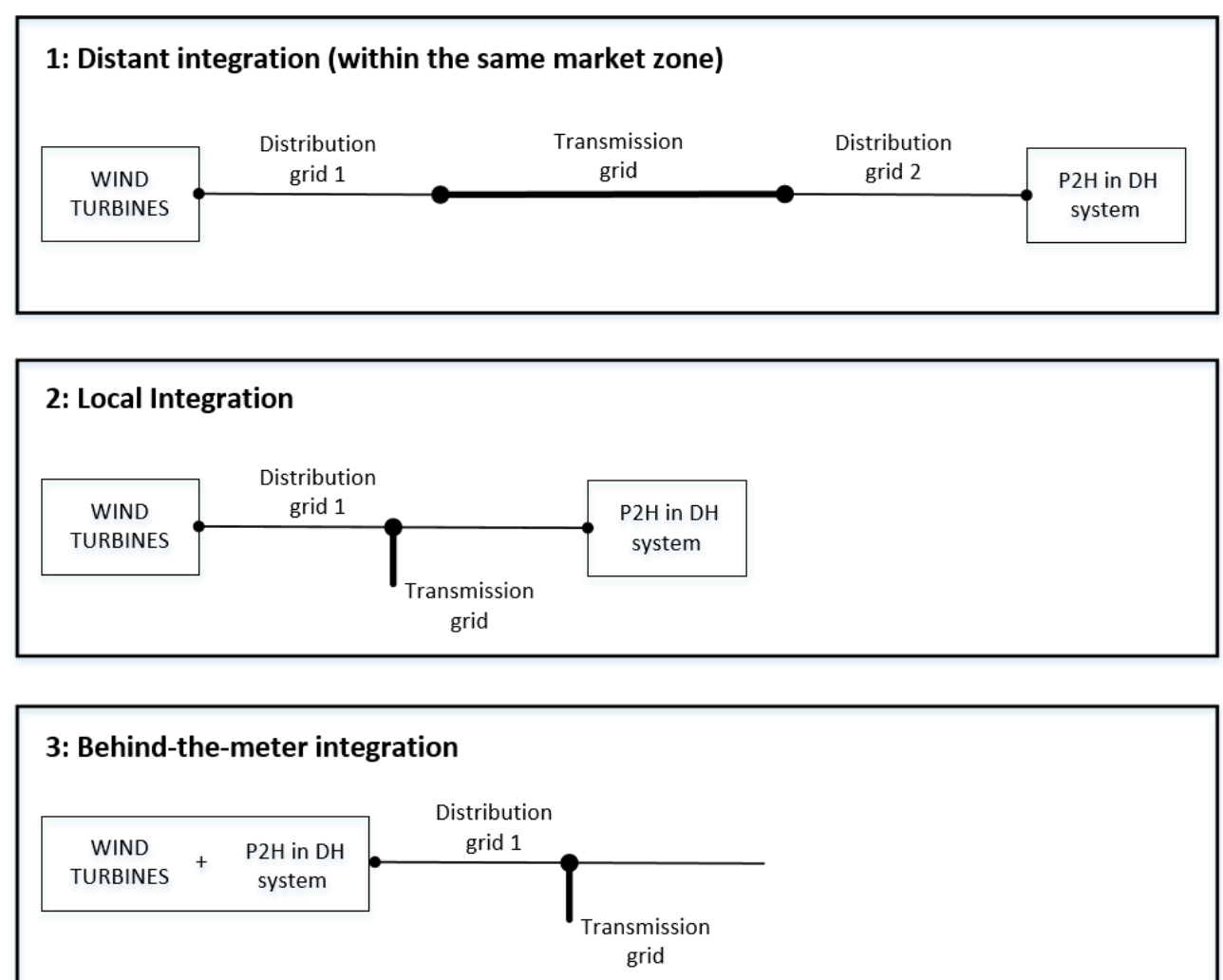

Figure 2. The location cases of cross-sector integration considered for the analysis. The location cases should not be regarded as either/or alternatives as they already co-exist and will probably still do so in the future. VRE: variable renewable energy; P2H: power-to-heat. 
Table 1. List of interviewed stakeholders. HP: heat pump; TSO: transmission system operator; DSO: distribution system operator.

\begin{tabular}{|c|c|c|}
\hline Stakeholder & Interviewee & Description \\
\hline DH Company & Hvide Sande DH [29] & $\begin{array}{l}\text { Hvide Sande DH owns wind turbines and } \\
\text { an electric boiler in a behind-the-meter } \\
\text { solution. }\end{array}$ \\
\hline DH Company & Ringkøbing DH [30] & $\begin{array}{c}\text { Ringkøbing DH owns an electric boiler and } \\
\text { a HP. }\end{array}$ \\
\hline Local Planning Authority & $\begin{array}{l}\text { Ringkøbing-Skjern } \\
\text { Municipality [31] }\end{array}$ & $\begin{array}{l}\text { Hvide Sande DH and Ringkøbing DH are } \\
\text { located in this municipality. } \\
\text { Ringkøbing-Skjern is a rural municipality } \\
\text { with high shares of VRE and ambitious } \\
\text { municipal energy targets. }\end{array}$ \\
\hline DSO & RAH Net [32] & $\begin{array}{l}\text { RAH Net is the local consumer-owned DSO. } \\
\text { Hvide Sande DH and Ringkøbing DH are } \\
\text { connected to RAH Net's electricity grid. }\end{array}$ \\
\hline TSO and Market Operator & Energinet [33] & $\begin{array}{c}\text { Energinet is the Danish TSO and market } \\
\text { operator. }\end{array}$ \\
\hline DH Consultant & EMD International [34] & $\begin{array}{l}\text { EMD International is an energy systems } \\
\text { software company that provides } \\
\text { consultancy to DH companies for the } \\
\text { improvement of their operations' strategy. }\end{array}$ \\
\hline
\end{tabular}

\section{Results}

The section is divided into four sub-sections, which answer research questions 1-4, respectively.

\subsection{The (Theoretical) Ability of the Consumer Cross-sector Ownership Model in Different Location Cases to} Address the Organisational Challenges of SESS

This sub-section answers research question 1 . The sub-section starts by explaining the operation of wind turbines and DH systems (i.e., the technical SES) in a co-ownership solution and continues with the analysis of the (theoretical) ability. The analysis builds up on the theoretical approach presented in Section 2.1. and Section 2.2.

\subsubsection{The Operation of the Wind Turbines and the DH System in a Co-Ownership Solution}

DH companies determine their optimal operational strategy (i.e., the one that meets the heat demand at the lowest possible cost) for the portfolio of technologies available and for every hour [22]. In Denmark, the portfolio may consist of CHP units, boilers, $\mathrm{P} 2 \mathrm{H}$ units, solar collectors, waste heat from nearby companies, and thermal storages [14]. Therefore, the calculation of the optimal operational strategy may include production and storage capacities, demand estimation, sun energy resource estimation, and fuel, heat, and electricity prices [22]. In the case of Hvide Sande, where the DH company also owns wind turbines, the calculation also includes wind resource estimation, the market price wind power could get, and the cost of self-consuming the wind power [22]. In this case, the operational strategy defines, among others, when to sell the wind power in the electricity market and when to self-consume it [22,29]. This means that, as suggested by the theoretical approach presented in Figure 1, the operation of the wind turbines and the $\mathrm{P} 2 \mathrm{H}$ unit are different in the co-ownership solution implemented in Hvide Sande and the separate ownership solution that is currently the norm.

Hvide Sande DH argues that they-deliberately-built a (smart) energy system that reduces the curtailment of the local wind turbines and the DH system's natural gas consumption while keeping in consideration the need for the wind power in the Danish electricity system. According to the DH company, they self-consume the wind power in periods with low power electricity market prices 
(i.e., when the demand/value of wind power in the market is low) and they sell it in periods with high electricity market prices (i.e., when the demand for power is high) [29].

EMD International pointed out that the understanding of "high" or "low" power prices by the DH company is subjective as it based on the alternatives that the DH company has to meet the energy demand. During sunny summer days, with low heating demand and high (cheap) heat production from the solar collectors, the DH company may not need (all) the wind production to cover the heat demand and could decide to sell the electricity at lower prices than in winter, when the alternative to self-consumption of wind power could be to operate the (expensive) natural gas boilers. Therefore, EMD International argues that the self-consumption or sale of wind power is not optimised from the Danish electricity system perspective, but from the DH company's perspective; i.e., by not making the wind power available in the Nord Pool market at all times, the co-ownership solution results in "sub-optimisation" of the electricity system [34].

The remark made by EMD International indicates that this stakeholder assumes that the (current) institutional incentive system optimises the operation of the electricity system. This is in line with Energinet's opinion [33]. However, the current institutional incentive system is still strongly influenced by the path dependency of a centralised and fossil fuel energy system with separated energy sectors [12] (as further explained in Section 3.2). One of the consequences is that the current market structure, in combination with electricity grid tariffs and taxes, results in curtailment of wind power (which is assumed not to have any market value) in moments with transmission grid congestions while flexible electricity demand from $\mathrm{P} 2 \mathrm{H}$ units in DH systems has not been activated and fossil fuels are being burnt to meet the heat demand of the DH systems $[29,30]$. This means that the curtailed wind power could have actually had a market value. Therefore, the optimisation of the national electricity (or energy) system through the electricity market and other institutional incentives is also questionable. Moreover, it is not clear if, under the current institutional incentive system, the separate ownership solution results in a better or worse optimisation of the energy resources than the co-ownership solution.

Some of the remarks made by EMD International [34] and Energinet [33] show a rather technocratic approach, where it is assumed that, while keeping the traditional single-sector or separate ownership solution, the right combination of institutional incentives will lead to the optimal operation of the energy system with regard to the political/societal goals. In contrast, scholars of sustainable socio-technical transitions advocate for creating spaces for experimentation and nourishing of niches in order to allow for innovation that could lead to fundamental changes, in this case, in the energy system [35-37]. Therefore, this preliminary study intends to break with the path dependency of the single-sector ownership approach and explore the (theoretical) ability of consumer cross-sector ownership to address the organisational challenges of SESs.

3.1.2. The Location Cases for Cross-Sector Integration and the Reduction of Overinvestments in the Electricity Grid

Grid issues are dependent on the characteristics of the local grid [7]. In the following, a basic technical analysis is provided of what, why, and where electricity grid issues may arise in Denmark as result of the increase of installed VRE capacity in a scenario where no mitigation strategy (e.g., grid reinforcement and expansion or cross-sector integration) is implemented. The technical understanding is essential to discuss the ability of the three different cross-sector integration cases presented in Figure 2 (i.e., distant, local, and behind-the-meter) to address grid issues in Denmark.

The grid issues introduced in the following and in Figure 3 are limited to the scope of the study and the inputs provided by the interviewed grid operators. The grid issues that could arise at transmission and distribution levels due to the implementation of $\mathrm{P} 2 \mathrm{H}$ units in $\mathrm{DH}$ systems are not discussed in the following. The reason is that, according to the interviewed grid operators, these issues are well-addressed by the current institutional incentive system, which promotes the flexible operation of P2H units in DH systems to avoid grid congestion [32,38]. 


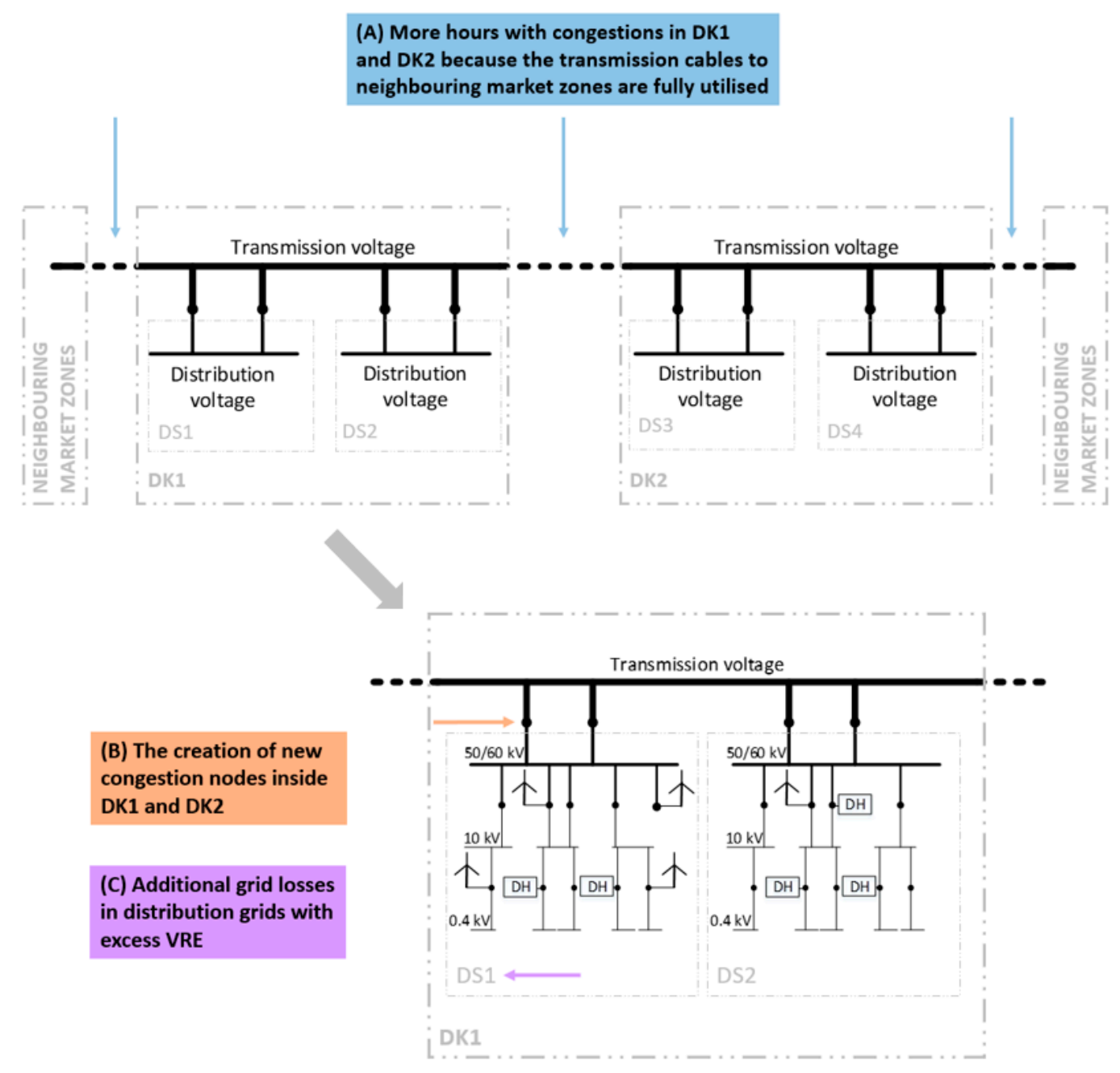

Figure 3. Potential grid issues that could be caused by increasing shares of VRE in a scenario where no mitigation strategy (e.g., grid reinforcement and expansion or cross-sector integration) is implemented illustrated on a schematic representation of the electricity grid in Denmark. DK1 and DK2 are the two electricity market zones in Denmark. DS1 and DS3 represent the distribution system areas with high shares of VRE and DS2 and DS4 the distribution system areas with high electricity and heat demand. The dashed lines represent the transmission voltage connection to other market zones. For a more detailed representation of the Danish electricity grid, see [39] and, e.g., [40]. DS: Distribution system.

Denmark's electricity system is rather decentralised compared to other EU and industrialised countries. About $50 \%$ of the electricity generation is directly fed into the electricity distribution grid nowadays, in contrast to $1 \%-2 \%$ in 1980 [41]. Wind turbines, photovoltaic panels, and small-scale CHP plants have been connected to the electricity distribution grids, which has required and resulted in stronger electricity distribution grids than in other EU countries [7]. The total installed electricity generation capacity in 2018 was 15,073 MW, divided into 6121 MW wind (4420 MW onshore and $1701 \mathrm{MW}$ offshore), $5402 \mathrm{MW}$ large-scale power plants (815 MW electricity only and $4586 \mathrm{MW}$ CHP plants), 1904 MW small-scale CHP plants, and 998 MW solar, 9 MW hydro, and 639 MW autoproducers [14]. In addition, Denmark is strongly connected to the neighbouring countries [39,42].

Currently, there is no congestion issue at the electricity distribution level in Denmark; the congestion issues are at the transmission level between market zones [7,33] (see Figure 3). This means that, in moments when the local electricity production e.g., in DS1, exceeds the local electricity demand in DS1, the excess electricity is exported to other parts of the electricity system through the transmission 
grid, e.g., to DS2 and even to DS4 and neighbouring market zones as long as the transmission grid connecting the different market zones is not congested.

In some Danish municipalities, wind and solar energy produce as much as $500 \%$ of the annual electricity demand (these are DS1 and DS3 in Figure 3). In Ringkøbing-Skjern municipality, the share is about $150 \%$. In others, the share is only about 1\% (these are DS2 and DS4 in Figure 3) [43]. At the beginning of 2017, the distribution system operator (DSO) NOE Net (which covers fully or partly the municipalities of Holstebro, Lemvig, Struer, and Herning [44]) estimated that there were periods when the exports from their grid were $1000 \%$ of the local electricity demand and expected this number to increase with the connection of the planned new wind turbines [45]. In a scenario where no mitigation strategy (e.g., grid reinforcement and expansion or cross-sector integration) is implemented, the increase of VRE capacity in DK1, DK2, and the neighbouring energy systems could result in:

(A) An increase amount of hours with transmission grid congestions in DK1 and DK2. DK1 and DK2 are the two electricity market zones in Denmark. This problem occurs in moments when the electricity production in DK1 and/or DK2 exceeds the electricity demand in DK1 and/or DK2 and the transmission connections to other market zones are fully utilised. The result is the curtailment of VRE by the power market [7].

(B) The creation of new congestion nodes inside DK1 and DK2. This may occur, e.g., because of congestions in the substations that connect DS1 and DS3 with the transmission voltage cables. Such an issue has already occurred for example in one of the transmission substations in Lolland municipality, where Energinet had to contact the local DSO to achieve down regulation of wind and solar power production. Currently this is only an issue for the transmission system operator (TSO), but it is expected to become a problem for the DSOs as well [46].

(C) Additional electricity grid losses at the distribution level in areas with excess VRE. Grid losses are proportional to the current (i.e., the power flow) and the distance that power is transported. In a centralised fossil fuel energy system (where the electricity is transported from the central power stations to the consumer through the transmission and distribution grids), the power consumption in a given distribution grid can be seen as the cause of the power flow in that given distribution grid and, consequently, of the grid losses in the given distribution grid too. However, in a renewable energy system (where large shares of the power production may be fed directly into the distribution grid and go upstream or downstream) the power flow in a given distribution grid could be caused by power consumption elsewhere in the system. This is the case when the local VRE production exceeds the local power consumption. In this sense, one could say that local excess power production from VRE creates additional grid losses in the local distribution grids where the excess power is produced.

Grid congestions between market zones or inside the market zone may be reduced by reinforcing and expanding the electricity grid and/or increasing flexible demand inside the congestion node through cross-sector integration. Increasing shares of VRE in neighbouring market zones and energy systems reduces the effectiveness of the first two options and demands for more cross-sector integration. Furthermore, cross-sector integration is expected to be strategic to decarbonise the H\&C and transport sectors [47]. Therefore, as argued in the theoretical approach, the coordination of investments in and operations of VRE and cross-sector integration infrastructure (e.g., $\mathrm{P} 2 \mathrm{H}$ in DH systems) - with regard to time, size, and location - will be essential to reduce unnecessary grid expansion and reinforcement (i.e., overinvestments in the electricity grid). At this point, it is important to highlight the relevance of the location aspect to that end. The congestions between market zones may be reduced by both distant and local cross-sector integration because it does not matter where the VRE production and the P2H demand are located within DK1 and DK2. In contrast, distant cross-sector integration is not suitable to address the congestions inside DK1 and DK2 because it cannot increase the flexible demand within the new congestion zone. To this end, local cross-sector integration would be necessary. Behind-the-meter cross-sector integration may also address the above mentioned congestion issues. However, it is not 
seen to be strictly necessary given that the congestion issues are not expected to happen at the wind farm connection point. The reason is that the Danish institutional incentive system does not allow DSOs to limit the connection of wind turbines and requires that DSOs make the necessary investments in the grid to enable the connection of new wind farms [32]. This is to avoid the discrimination of power producers.

Regarding the additional grid losses in areas with excess VRE, DSOs have expressed different opinions. In Denmark, there is an "equalization scheme" between all the Danish DSOs that is used to cover the additional grid investments and expenses related the connection of new wind turbines to electricity distribution grids [32,45]. The DSO RAH Net states that the expenses related to the additional grid losses are covered by the equalization scheme [32]. In contrast, the DSO NOE Net argues that the scheme does not adequately cover the additional grid losses [45]. NOE Net adds that additional grid losses have significantly increased in areas with high shares of VRE and raise the electricity bills of the local consumers. NOE Net demands a reform of the scheme [45] and RAH Net points out that avoiding long distance transportation of electricity would reduce grid losses [32]. In this respect, both local and behind-the-meter cross-sector integration could provide a suitable solution to reduce additional grid losses by increasing the local power demand in moments of excess VRE production.

Energinet pointed out that $\mathrm{P} 2 \mathrm{H}$ has a strong seasonal profile [33]. Therefore, none of the cross-sector integration cases considered in this study provides a full solution to the grid issues presented in this section. Hence, other integration technologies (such as power-to-gas) are expected to be necessary along with grid expansion and reinforcement $[8,12,38]$.

\subsubsection{Consumer Ownership and Local Acceptance of Wind Turbines}

The majority of onshore wind turbines in Denmark have citizen ownership, which is very diverse (see [11]). From the middle of the 1990s, a tendency for distant and exclusive commercial and citizen ownership has been observed in the country, which significantly differs from the previous tendency for local and inclusive citizen ownership [11]. The new ownership trend is one of the reasons for the observed increase of local opposition to wind turbines [6,11].

In Denmark, $95 \%$ of the DH systems are owned either by a consumer cooperative or a municipal company [11]. The interests of the local DH consumers are strongly represented in the boards of these companies and profits are shared in the form of lower heat bills [27]. The implementation of new turbines or the purchase of existing ones by these DH companies is dependent on a beneficial business economy and the support of the local heat consumers. In the case of Hvide Sande, the purchase of the wind turbines was approved in a general assembly in August 2018 [48]. This means that the ownership of consumer and municipal DH companies in Denmark is local and inclusive [11]. Consequently, based on the theoretical background presented in Section 2.2.2, the ownership of local wind turbines by such local DH companies might bring some advantages with regard to local acceptance compared to the general trend for exclusive and distant ownership observed for the separated ownership solutions [11], where the local community has very limited decision power and access to benefits. The ownership of local wind turbines by distant $\mathrm{DH}$ companies would not provide any advantage over the current trend.

When comparing the case of co-ownership with behind-the-meter cross-sector integration and the case of co-ownership with local cross-sector integration, the former has advantages over the latter. In the behind-the-meter case, the closest neighbours to the wind turbines are expected to be connected to the DH system. In contrast, in a local cross-sector integration case, the wind turbines could be placed away from the DH system, probably in the countryside, where the closest neighbours would use individual heating [32]. In this case, the closest neighbours to the wind turbines, i.e., those that will experience the local impacts the most, would not benefit from the ownership of the wind turbines by the DH company. Such local imbalance between benefits and negative impacts should be addressed in order to ensure local acceptance. 


\subsubsection{The Attractiveness of VRE and $\mathrm{P} 2 \mathrm{H}$ for $\mathrm{DH}$ Companies}

The co-ownership of wind turbines and $\mathrm{P} 2 \mathrm{H}$ by DH companies would improve the economy of the wind turbines and the DH company because:

1. Coupling the wind turbines with the flexible demand of the DH system would to some extent resolve the merit-order-effect and the curtailment problems when the wind turbines and the flexible electricity demand are placed in the same congestion node [21].

2. Onshore wind turbines are the cheapest source of electricity in Denmark [49]. Therefore, it would be cheaper for a flexible consumer to self-consume electricity from his wind turbines than buy electricity from a wind power producer (either via the spot market or through peer-to-peer trading). This is because, when buying electricity from a producer, the consumer would have to pay for the cost of producing the wind power and for some benefits for the wind power producer. DH companies who owned wind turbines in windy areas would have an additional advantage because the levelised cost of wind power in these areas is even lower.

3. The DH system could be entitled to a reduction of electricity grid tariffs for the self-consumed electricity based on the advantages it provides for the reduction of overinvestments in the electricity grid expansion and reinforcement (see Section 3.1.2). In this sense, the co-ownership in the behind-the-meter and local cross-sector integration cases would have an economic advantage over the co-ownership in the distant cross-sector integration case.

\subsubsection{Summary}

This sub-section has analysed the (theoretical) ability of the cross-sector consumer ownership solution implemented at the different location cases presented in Figure 2 to address the organisational challenges of SESs. In the following, a summary of the results is provided.

The results support the argument for the need of coordinating investments (in VRE, P2H in DH systems and the electricity grid) and operations (of VRE and P2H units) with regard to time, size, and location in order to reduce overinvestments in the electricity grid when introducing high shares of VRE. As suggested by the theoretical background, the necessary coordination is expected to be easier in the co-ownership solution than in the separate ownership solution because the wind turbines are regarded as one of the components of the DH system [22,29] and the decisions are made by one single stakeholder, i.e., the DH company. Furthermore, the analysis emphasises the relevance of the location aspects to reduce overinvestments in the grid. Both distant and local cross-sector integration are suitable to reduce congestions in DK1 and DK2 but only local cross-sector integration may address the local grid issues (i.e., the creation of new congestion nodes inside the market zones and the additional grid losses in distribution grids with excess VRE). Behind-the-meter cross-sector integration does contribute to alleviate the above mentioned issues too. However, it is not seen to be strictly necessary given that the congestion issues are not expected to happen at the wind farm connection point.

The ownership of local wind turbines by local consumer- and municipal-owned DH companies may enhance local acceptance as these companies have local and inclusive forms of citizen ownership [11], as recommended by the theoretical background. Besides, the analysis indicates that the behind-the-meter solution is better than the local cross-sector integration solution for local acceptance. In the former, the closest neighbours to the wind turbines are expected be connected to the DH system, whereas in the latter the wind turbines could be out in the countryside where the closest neighbours would use individual heating instead.

Finally, the co-ownership is expected to increase the attractiveness for DH companies to invest in wind turbines and $\mathrm{P} 2 \mathrm{H}$ units, as suggested by the theoretical approach. This is particularly so in windy areas, where the levelised cost of wind power is even lower than the country average, and with behind-the-meter or local cross-sector integration solutions, where a higher reduction of electricity grid tariffs for the self-consumed electricity could apply (based on the advantages they provide for the reduction of overinvestments in the electricity grid expansion and reinforcement). 
All in all, it may be concluded that especially the local cross-sector integration case with the co-ownership of wind turbines and P2H units by DH companies could (theoretically) provide several benefits for the implementation of SESs in Denmark. These are reduction of overinvestments in grid expansion and reinforcement, improved economic attractiveness of wind turbines and $\mathrm{P} 2 \mathrm{H}$ units, improved utilisation of local wind power, reduction of burning of fuels, better economy for the local DH consumers, better economy for the local electricity consumers, and improved local acceptance of wind turbines. Ultimately, this ownership model could have the potential to accelerate the implementation of SESs. Therefore, it is deemed relevant to analyse the possibilities to implement it under the current Danish incentive system.

\subsection{The Current Institutional Incentive System for Cross-Sector Consumer Ownership in Denmark}

This sub-section answers research question 2. The sub-section analyses how the current Danish institutional incentive system encourages/discourages the different location cases of cross-sector consumer ownership presented in Figure 2. In line with the interrelations presented in Figure 1, some of the institutional incentives introduced in this section directly influence the implementation and operation of the technical SES; others directly influence the actor participation and interaction in the energy system; and, ultimately, all institutional incentives indirectly influence both. The analysis of the institutional incentives is divided into the role and possibilities of electricity grid operators, electricity grid tariffs and taxes, the design of the electricity spot market, and the lack of targeted incentives for local cross-sector integration.

\subsubsection{The Role and Possibilities of Electricity Grid Operators}

Under the current legislation, grid operators' are responsible for addressing grid congestion issues, such as those that emerge from increasing shares of VRE or the electrification of the H\&C and transport sectors. However, the actions they may implement are limited to grid reinforcement and expansion and to introduction of new grid tariffs, which need to be approved by the Danish Utility Regulator. This means that the possibility for grid operators to promote, e.g., the necessary cross-sector integration to reduce grid congestions caused by increasing shares of VRE is very limited and that grid operators might be forced to overinvest in the electricity grid to address congestion issues. This limitation is one of the reasons why the "electricity integration over distance" strategy [38] (i.e., the expansion and reinforcement of the electricity grid) has been (and still is) the main VRE integration strategy implemented in Denmark. This is illustrated, e.g., by the construction of two new transmission connections to the Netherlands and the United Kingdom [50], whereas only $1.1 \%$ of the DH demand is supplied by HPs [14].

\subsubsection{Electricity Grid Tariffs, and Taxes}

In Denmark, the electricity grid costs are distributed among consumers following the waterfall principle. This means that the grid tariff to be paid by the consumer depends on the voltage level of his electricity grid connection and that the consumer pays for the share of the grid expenses he generates in his connection's voltage level and all of the upper voltage levels. This principle was adopted in a fossil fuel energy system, where electricity was produced centrally and transported to the consumption point through transmission lines first and through distribution lines of decreasing voltages afterwards, and where the consumer used all the upper voltage levels of the grid. However, with an increasing share of power production being directly connected to the distribution grid and flowing both downstream and upstream, the waterfall principle might not result in a fair distribution of electricity grid costs for the consumers any longer. Furthermore, the waterfall principle implies that a DH system will have to pay the same grid tariffs when self-consuming or purchasing electricity from a nearby wind farm as when self-consuming or purchasing electricity from a distant wind farm [51]. However, the DH system that consumes electricity from a nearby wind farm in moments of excess 
electricity is helping to reduce grid costs, as concluded in Section 3.1.2. Hence, the discussion of new cost distribution principles and grid tariffs becomes increasingly relevant.

In Denmark, the electricity taxes and grid tariffs (which, in the case of Hvide Sande, summed approximately $70 \mathrm{EUR} / \mathrm{MWh}[22,52,53]$ ) have made the private economy of $\mathrm{P} 2 \mathrm{H}$ units for DH systems worse than that of other alternatives (e.g., biomass boilers and solar collectors, for which taxes do not apply) - even though the socio-economy of HPs is better [54]. As a result, only a few P2H units were installed in the DH systems of the country up to 2018 [55], and their utilisation has been limited [29,30]. Nevertheless, new economic incentives have been recently introduced to promote $\mathrm{P} 2 \mathrm{H}$ in $\mathrm{DH}$ systems. These include the reduction of the electricity tax for heating from approximately $41 \mathrm{EUR} / \mathrm{MWh}$ to 21 EUR/MWh from 2021 [56]. In addition, in 2017-2018, approximately EUR 6.87 million in subsidies were granted to DH companies with small-scale CHP units to cover up to $15 \%$ of the investment in an electric HP. The subsidy was granted through application processes. In total, 29 projects summing 48.8 MW were granted and are supposed to be implemented in 2019-2020. The phasing out of the public service obligation (PSO) electricity tax and the energy companies' energy saving scheme are also expected to improve the economy of DH HPs. [57-59] The new economic incentives are regarded as a positive step towards the promotion of both distant and local cross-sector integration because they are expected to result in several DH companies investing in HPs and a significant increase of the annual hours of operation of the P2H units according to Hvide Sande DH, Ringkøbing DH, and EMD International $[29,30,34]$. However, the actual positive impacts of the new institutional incentives for $\mathrm{P} 2 \mathrm{H}$ in DH systems are still to be seen and their sufficiency to be evaluated.

Regarding the co-ownership of wind turbines and $\mathrm{P} 2 \mathrm{H}$ by DH companies, the institutional economic incentives are different for behind-the-meter solutions and any technical solution that utilises the public grid for the electricity consumption (i.e., distant and local cross-sector integration). Currently, no electricity taxes or grid tariffs need to be paid for the wind power that is self-consumed in a behind-the-meter solution [29]. This requires that both the wind turbines, the private cable, and the P2H unit(s) are placed on the same land (with the same cadastral number) $[29,51,60]$. This requirement significantly limits the potential for behind-the-meter cross-sector integration of wind turbines and $\mathrm{P} 2 \mathrm{H}$ in $\mathrm{DH}$ systems because wind turbines are usually placed in the countryside, away from the DH systems $[29,30,32]$. Therefore, in many cases, the implementation of the behind-the-meter solution would require the construction of $\mathrm{DH}$ pipelines to the wind farm (where the $\mathrm{P} 2 \mathrm{H}$ unit would need to be placed), which could significantly/totally reduce the attractiveness of the investment [30].

Full electricity grid tariffs and taxes need to be paid by the DH company for the electricity that is self-consumed utilising the public grid [29], which completely discourages the co-ownership solutions with distant and local cross-sector integration. Blanco et al. [22] studied the operation and system costs of the DH system in Hvide Sande and assessed the impact of electricity taxes on the rate of wind power that would be self-consumed/sold by the DH company. Their results show that, if the total value of the applicable electricity taxes (about 48 EUR/MWh at that time) had to be paid for the self-consumed electricity, $100 \%$ of the wind power production would be sold to the spot market. In other words, it would be more expensive to self-consume wind power than sell the electricity at the Nord Pool market and use the other energy sources and technologies to meet the heat demand instead. The results obtained by Blanco et al. also show that, despite the additional revenue from the sale of wind power, the total system costs would increase significantly compared to the situation where no electricity taxes were paid for the self-consumed wind power.

\subsubsection{The Design of the Electricity Spot Market}

Denmark is part of the Nord Pool electricity market and has two market zones, DK1 and DK2. Producers and consumers may trade through the Nord Pool market or directly between each other. Peer-to-peer trading is possible as long as the producer and the consumer are placed within the same market zone and the production and consumption occur simultaneously [51]. 
In Section 3.1.4. it is argued that self-consuming wind power should be cheaper than buying electricity from the Nord Pool market because onshore wind turbines are the cheapest source of electricity in Denmark [49]. However, this does not apply under the current institutional incentive system and with the current spot market design. Energinet [33] and Ringkøbing DH [30] pointed out that the cheapest electricity prices do not necessarily match the periods with local wind resource availability. Ringkøbing DH mentioned: "Other times the wind is not blowing here, but my boiler is running and my price [for purchasing electricity at the Nord Pool market] is -125 DKK [per MWh]"; this is about -17 EUR/MWh [30].

The levelised cost of onshore wind power in Denmark is about 35 EUR/MWh [49]. Figure 4 shows that the number of hours at the Nord Pool with spot market prices below that value has been considerable in DK1 in the last years. Based on a preliminary analysis, the values suggest that it would be unattractive for DH companies to invest in wind turbines, unless a reduction of grid tariffs and taxes would apply for the self-consumed electricity. This was the case in Hvide Sande [29]. At the same time, the values indicate that investments in wind turbines might not be attractive in a separate ownership solution either, unless support schemes or other arrangements such as beneficial PPAs are in place. This idea is supported by the results obtained and the conclusions drawn by Djørup et al. [17], who further argue that "the current electricity market structure is not able to financially sustain the amounts of wind power necessary for the transition to a $100 \%$ renewable energy system" (p. 148) in Denmark. This means that, in order to further the implementation of wind power, the market structure will need to be changed so that consumers pay at least the levelised cost of wind power and a reasonable profit for the producer. After such a change, the self-consumed wind power should be cheaper than the purchased wind power.

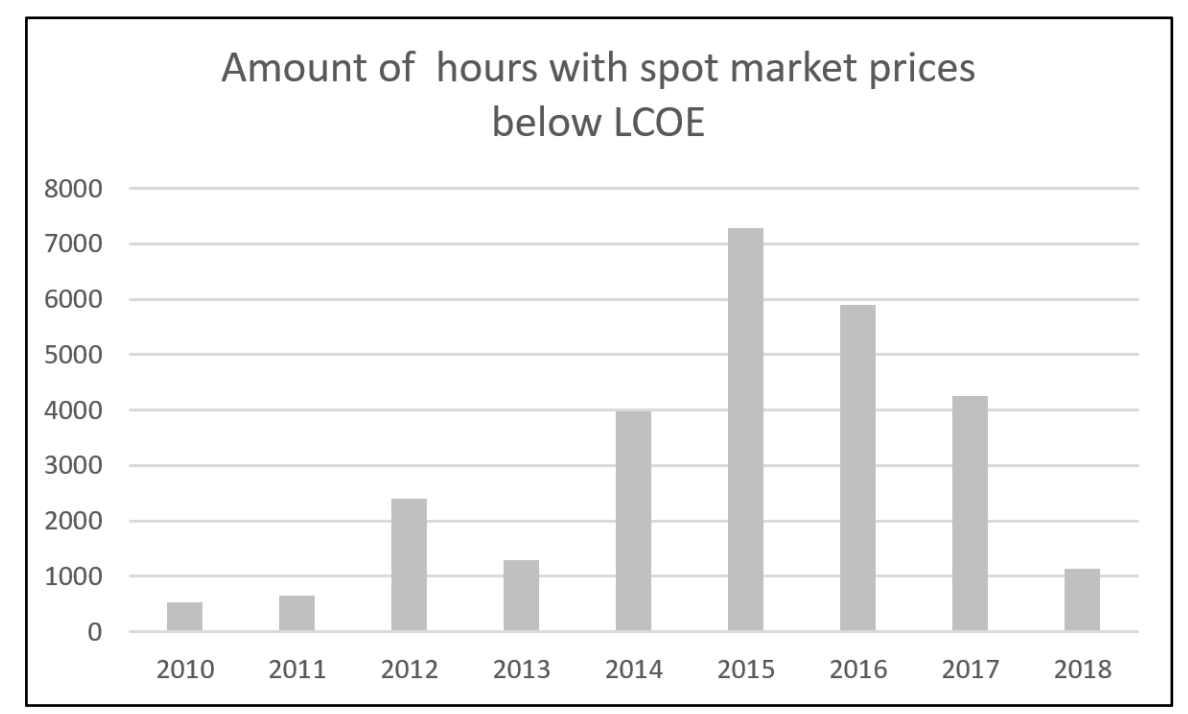

Figure 4. Number of hours per year with spot market prices below the levelised cost of wind power in DK1. Based on data from [61]. LCOE: Levelised cost of energy.

Changes in e.g., ownership regulation, spatial planning regulation, the size of wind projects, and the social normative perception of wind power have been identified as causes for the lowering of wind projects with local and inclusive ownership in Denmark [11,62]. On top of that, the abolition of feed-in tariffs in 2018 and the implementation of the tender scheme introduces an extra burden and increased risk for (small) local initiatives $[18,19]$ and could reduce their number even further. This works against the goal of enhancing local acceptance of wind turbines. 


\subsubsection{Lack of Specific Incentives for Local Cross-Sector Integration}

There are no specifically targeted institutional incentives for local cross-sector integration or local balancing. There is no economic incentive that encourages the activation of the flexible power consumption in a given location within the specific market zone, nor any economic incentive to promote a faster implementation of local cross-sector integration, e.g., in areas with very high/low shares of VRE. This means that the institutional incentive system does not address the issue of the creation of new congestion nodes inside DK1 and DK2 in any way [46], which could lead to overinvestments in the electricity grid. The lack of incentives to address the issue could be explained by the fact that the creation of new congestion nodes is not yet an important technical problem [7]. However, it is expected to become a problem in the near future [46]. In fact, Energinet acknowledges that the distant/nearby location of VRE and flexible electricity demand could have an impact in the grid and argues that the electricity grid should not be "ignored" in the spatial planning of VRE and cross-sector integration technologies [33].

\subsubsection{Summary}

This sub-section has analysed how the current Danish institutional incentive system encourages/discourages the cross-sector consumer ownership at the different location cases presented in Figure 2 (i.e., distant, local and behind-the-meter). The results presented in this section are in line with the theoretical approach presented in Figure 1, which suggests that the institutional incentive system influences the implementation and operation of SESs by encouraging/discouraging certain technical and actor participation and interaction characteristics, which in turn influence each other.

All in all, it may be concluded that the current institutional incentive system has promoted grid expansion and reinforcement over cross-sector integration for the introduction of VRE in the electricity system [12]. This is seen as problematic given that the potential of this strategy is limited as increasing shares of VRE are implemented in neighbouring market zones and energy systems. Therefore, the cross-sector integration approach is expected to be essential to improve wind power utilisation and business economy $[9,12]$ and reduce overinvestments in the electricity grid [8]. The new incentives for $\mathrm{P} 2 \mathrm{H}$ in $\mathrm{DH}$ systems are seen as a positive step to promote distant and local cross-sector integration, although the results of the policy are still to be seen and evaluated. However, the lack of institutional incentives that specifically target local cross-sector integration in areas with high shares of VRE is seen as problematic. This should change in order to address local grid issues (i.e., the creation of new congestion nodes inside DK1 and DK2 and the additional grid losses in distribution grids in areas with excess VRE).

The current institutional incentives do encourage to some extent the co-ownership of wind turbines and $\mathrm{P} 2 \mathrm{H}$ units by $\mathrm{DH}$ systems in a behind-the-meter solution by not applying any electricity grid tariffs and taxes to self-consumed electricity. However, the cases where the behind-the-meter solution may be implemented are very limited because of the requirement of having the wind turbines, the private cable, and the $\mathrm{P} 2 \mathrm{H}$ unit on the same piece of land (with the same cadastral number) $[29,30]$. In contrast, the current institutional incentives completely discourage the co-ownership with local or distant cross-sector integration (i.e., the solutions where the public grid is used) by requiring that the full electricity grid tariffs and taxes are paid for the self-consumed electricity [29].

It may be concluded that the current institutional incentive system seems to block all the benefits that the co-ownership of wind turbines and $\mathrm{P} 2 \mathrm{H}$ units by $\mathrm{DH}$ companies in a local cross-sector integration solution could (theoretically) offer for the transition to a renewable SES.

\subsection{Possibilities for Improving the Current Institutional Incentives}

This sub-section answers research question 3. Based on the results presented in Section 3.1. and Section 3.2, this sub-section introduces possible improvements for the current Danish institutional incentive system. Most importantly, local cross-sector integration should be further promoted in order 
to avoid overinvestments in the electricity grid and improve wind economy. This would reduce the electricity costs to be paid by the consumers. Several institutional incentives could be implemented to that end:

- Geographical bids for the regulating power market in order to enable local balancing, as suggested by Energinet [46] and EMD International [34].

- New (TSO and DSO) grid tariffs to activate flexible demand in a given location in periods of excess electricity generation, as suggested by Ringkøbing DH [30]. "I can prove to them [to the local DSO] mathematically that they would sell more electricity to me [and] make more money and [that] I would make more DH to a lower price on the electrical boiler, if they lowered their price [the electricity distribution tariff]" said Ringkøbing DH [30]. The reconsideration of the waterfall principle for the distribution of grid costs would also be pertinent here.

- Subsidies on investments in VRE and/or P2H in targeted areas. The subsidies could be paid by the savings that would be obtained from not having to reinforce or expand the electricity grid. This could be facilitated by modifying the current legislation so that grid operators could promote the implementation of cross-sector integration technology (on the right time, size and location), when this wasestimated to be a more cost-effective solution from a socio-economic perspective.

Note that no analysis or assessment of the amount and location of the possible new congestion nodes inside DK1 and DK2 has been found, which makes the present understanding of the problem preliminary. Such thorough analysis would be necessary to evaluate which institutional incentive measures would be needed/suitable to tackle the issue. Therefore, the above points should be understood as interim suggestions that require further research in order to define concrete and final policy recommendations.

The promotion of local cross-sector integration could target either the separate ownership solution or the co-ownership solution analysed in this study or both of them. The results of the analysis of the (theoretical) ability of cross-sector consumer ownership to address the challenges of SESs suggests that the co-ownership solution has the additional advantage of improving wind utilisation and economy and of enhancing local acceptance. Therefore, this preliminary analysis suggests that the co-ownership solution should be promoted, e.g., through the reduction of grid tariffs and taxes, as suggested by $[22,29,30]$. However, it would be advisable to increase the knowledge about the co-ownership solution and its potential implications for the $\mathrm{DH}$ and electricity consumers before promoting it. EMD International and Energinet expressed their concern about the fact that the DH company would not pay grid tariffs and taxes [33], which would then need to be covered by other consumers and tax payers [34]. This concern entails an implicit assumption that grid costs would not be reduced by increasing the share of local utilisation of wind power. The results presented in Section 3.1.2. contradict this assumption. In contrast, Hvide Sande DH understands that the production of heat with their own wind turbines is similar to the production of heat with their own solar collectors-they do not have to pay any taxes for the heating they produce from sun energy, nor for the heating they produce from wind energy [29]. Furthermore, DH companies in Denmark do not pay taxes for the biomass they consume either as result of political preferences. The above considerations and mismatch in opinions/perspectives resembles the debates related to individual self-consumption (or individual prosumers) that are taking place in the EU and other industrialised countries, here applied to collective self-consumption (or collective prosumers). As mentioned, a more thorough analysis than the one presented here would be necessary to shed light on this discussion and design adequate institutional incentives for SESs.

Ringkøbing DH also pointed out that "the rules could be better [so that DH companies could own wind turbines and reduce their fuel consumption] but, on the other hand, you know, we are very good at operating the DH system, the HPs and the gas engines, and the CHP and all the pipes in the city and so on. Sometimes when you start thinking on a new market, like you own the wind turbines also, maybe you are not that good at that. Maybe some other guys are better at that" [30]. This comment 
holds an important observation about the potential need for DH companies to develop new core competences for the transformation of the business model from a DH company into a smart energy company. However, it shall be noted that many DH companies in Denmark already operate CHP units, which means that they do have knowledge about the electricity market. Besides, the planning of the wind turbine project could be done with the help of a specialised consultancy firm, like wind cooperatives have usually done.

What it is clear is that the promotion of the co-ownership model together with the local cross-sector integration solution should also include measures to create benefits for the nearby neighbours who are not consumers of the DH systems. This could be achieved, e.g., by giving them the priority for the purchase of the $20 \%$ of the shares that have to be offered to local residents by law [63] or by creating a local wind foundation that would own a part of the wind farm and use the benefits for, e.g., supporting energy renovations and investments in individual HPs outside the DH systems.

\subsection{Future Perspectives for Research on Ownership and SESs}

This sub-section answers research question 4 . The sub-section introduces the issues regarding ownership and SESs that have been identified for further research in this preliminary study.

The suitability of different ownership models to address the organisational challenges of implementing and operating SESs are still rather unknown. This article contributes to build up the knowledge on the topic. However, the results are not conclusive on whether or not local consumer ownership has a higher ability than other ownership models to facilitate and coordinate investments and operations, as suggested by Hvelplund and Djørup [3]. The hypothesis should be tested using a broader scope of the technical (smart) energy system than the one chosen for this exploratory study and in different contexts of actor participation and interaction.

Besides, cross-sector ownership is still rather unknown for medium- and large-scale energy systems. Possibly the only exemption here is CHP plants connected to DH systems. This is not surprising given that cross-sector integration is at early stages even in countries and local regions challenged by the current high shares of VRE. Interesting enough, the idea of cross-sector ownership could have some potential for SESs, as concluded in this article. This opens up for investigating the possibility for energy companies to transition from single-sector energy companies to smart energy companies. Many DH companies in Denmark own CHP plants and, therefore, already provide two energy products, i.e., electricity and heat. In a similar way, the local electricity company or the (current) local wind cooperative could own, e.g., wind turbines, HPs, and electrolysers to supply electricity, heat and hydrogen. It would be relevant to analyse further whether owning a cross-sector energy technology portfolio would provide any competitive advantage in a renewable energy system and under which institutional incentive system. If so, the necessary organisational innovation and strategies to implement it would also be of relevance for further research. This could lead to considerations about bundling of energy sectors and/or (some) services, which would require to assess the implications for energy consumers and study the legal implementation. In this line, it would be advisable to study under which circumstances the smart energy company should or should not be allowed to include a natural monopoly (i.e., electricity, $\mathrm{DH}$, and gas grids) in the portfolio based on the potential implications for the consumers.

\section{Discussion}

This article presents an exploratory analysis of an interdisciplinary character for which only a few stakeholders have been interviewed. These are the ones that are considered relevant according to the theoretical approach presented in Figure 1 and they are mainly connected to the case of Hvide Sande, which, to the best knowledge of the author, is the only existing case in Denmark for now. Interviewing other DSOs, DH companies, and wind turbine companies could provide a more detailed understanding about the studied issues and show any strong, fair, or weak agreements/disagreements with the views/information collected in this study. Interviewing other DSOs would be necessary, e.g., 
to find out the general opinion on the equalization scheme and on its adequacy to cover the expenses related to additional distribution grid losses in areas with excess VRE. In addition, it might help to get an idea about where the new congestion nodes inside DK1 and DK2 might appear and the seriousness of this issue. Interviewing other DH companies would be necessary, e.g., to find out their opinion on and interest in investing in wind turbines and their plans for investing in HPs after the new economic incentives. Therefore, a more thorough analysis, based on interviews with a larger number of these stakeholders, would result in better-grounded policy recommendations. Apart from that, interviewing, e.g., DH consumers, the Danish Utility Regulator, the Tax Ministry, or the Energy Ministry would make it possible to collect these stakeholders' opinion on the analysed ownership model and the interim policy recommendations. Furthermore, the study could be extended to include other technologies (e.g., electrolysers) and other countries (e.g., the EU Member States). However, these are out of the scope of the exploratory analysis presented here.

In spite of the limitations of the chosen theoretical approach and methods, this study is sufficient to show that the location of VRE and sector integration infrastructure (e.g., P2H) does matter when it comes to the development of the electricity grid and the attractiveness of investments in VRE. This is in line with knowledge about grid congestion (see, e.g., [7]) and about innovative forms to reduce wind curtailment (see, e.g., [21]), presented in the theoretical approach. The study is also sufficient to show the advantages of the co-ownership with the behind-the-meter solution (when the wind turbines and the DH system are close enough) to enhance the attractiveness of investments in wind turbines and P2H units as well as local acceptance of wind turbines in Denmark. Moreover, the study suggests that, under an improved institutional incentive system, the co-ownership with the local cross-sector integration solution could also provide these benefits. However, further research is necessary to understand the full implications of such ownership model and define suitable institutional incentives to promote local cross-sector integration either with co-ownership, with separate ownership, or both.

The study takes as the point of departure an empirical case in Denmark. Here the material resources, the cultural and cognitive characteristics, the political process and system, and the institutional system may diverge from the conditions in other EU countries and therefore also result in other technical and organisational solutions for the energy system, as indicated by Figure 1 in the theoretical approach. In Denmark, wind power provides almost half of the final annual electricity demand [13] and onshore wind power is the cheapest source of electricity [49]. Denmark has a rather decentralised electricity system (with about $50 \%$ of the electricity production directly fed into the distribution grids [40]), which has required and resulted in stronger distribution grids than in other EU countries [7]. Moreover, the Danish electricity system is very well connected to the neighbouring countries through transmission cables [41,42] and has a high integration of DH [14]. Obviously, this puts Denmark in an advantageous position when it comes to handling high shares of VRE compared to other EU countries. Furthermore, the potential within the present Danish technological configuration for the ownership of wind turbines by DH companies is larger than in other countries where, e.g., the shares of $\mathrm{DH}$ are still low or the cheapest electricity source is another, e.g., hydropower. Nevertheless, the understanding of how different location cases of cross-sector integration (using different technologies) could reduce electricity grid expansion and reinforcement needs while creating the necessary space for high shares of VRE and the electrification of the $\mathrm{H} \& \mathrm{C}$ and transport sectors is as relevant in other EU countries [8]. One could even think that EU countries with weaker electricity grids could significantly benefit from early considerations regarding locational aspects of cross-sector integration. In this respect, they could find suitable organisational solutions for cross-sector integration that helped avoid overinvestments in the grid. Moreover, a larger deployment of DH systems is recommended to decarbonise the H\&C sector [64] and to reduce the costs of integrating high shares of VRE [8] in the EU.

It should also be highlighted that citizen ownership in general and consumer ownership in particular is much more common in Denmark than in many EU countries [65]. As other EU countries advance towards more decentralised energy systems and with EU energy policies that aim at putting the consumer at the centre of the energy transition and at increasing open and participatory forms of 
citizen ownership for renewable energy projects, increasing shares of consumer ownership could be expected across the EU too. In this regard, advancing the understanding about on-site and off-site collective prosumers and the advantages and disadvantages they offer in a context of developing renewable SESs becomes increasingly important for all EU Member States. On the other hand, it is important to note that the regulation and ownership of DH systems and companies is very diverse in the EU [66,67]. This means that, in other EU countries, DH ownership is not necessarily local and inclusive, i.e., local DH consumers might have little or no power over the decisions of the DH company and the reduction of DH system costs might not be reflected in the heat bills of the consumers. Consequently, the ownership of local wind turbines by the DH company that owns the local DH system might not enhance local acceptance of wind turbines in other EU countries.

Finally, it shall be noted that the current regulation that dictates unbundling of energy sectors/services could be an impediment to implementing cross-sector ownership solutions such as the one presented in this study in other EU countries. On the other hand, this does not mean that the existing regulation should define/limit the organisational solutions of the future if innovative options are proven beneficial to meet the societal goals of the transition to a renewable energy system.

Funding: This research and the APC were funded by European Union's Horizon 2020 research and innovation programme under the Marie Skłodowska-Curie grant agreement number 765515. The article reflects only the author's view and the Research Executive Agency is not responsible for any use that may be made of the information it contains.

Acknowledgments: I thank all the interviewees for their contribution and their time. I also thank Frede Hvelplund and Karl Sperling for their valuable comments to improve the manuscript. Finally, I also thank all those who have helped me understand the technical problems related to the electricity grid.

Conflicts of Interest: The author declares no conflict of interest. The funders had no role in the design of the study; in the collection, analyses, or interpretation of data; in the writing of the manuscript, or in the decision to publish the results.

$\begin{array}{ll}\text { Abbreviations } & \\ \text { CHP } & \text { Combined heat and power } \\ \text { DH } & \text { District heating } \\ \text { H\&C } & \text { Heating and cooling } \\ \text { HP } & \text { Heat pump } \\ \text { DSO } & \text { Distribution system operator } \\ \text { LCOE } & \text { Levelised cost of energy } \\ \text { PPA } & \text { Power-purchase-agreement } \\ \text { P2H } & \text { Power-to-heat } \\ \text { SES } & \text { Smart energy system } \\ \text { TSO } & \text { Transmission system operator } \\ \text { VRE } & \text { Variable renewable energy }\end{array}$

\section{References}

1. IPCC. Global Warming of $1.5^{\circ}$ C. Summary for Policymakers; IPCC: Geneva, Switzerland, 2018.

2. European Commission. Roadmap 2050; European Commission: Brussels, Belgium, 2012.

3. Hvelplund, F.; Djørup, S. Consumer ownership, natural monopolies and transition to $100 \%$ Renewable Energy Systems. Energy 2019, 181, 440-449. [CrossRef]

4. Innovation and Disruption at the Grid's Edge: How Distributed Energy Resources are Disrupting the Utility Business Model, 1st ed.; Sioshansi, F.P. (Ed.) Academic Press: London, UK, 2017; ISBN 978-0-12-811758-3.

5. Burger, S.P.; Luke, M. Business models for distributed energy resources: A review and empirical analysis. Energy Policy 2017, 109, 230-248. [CrossRef]

6. Ladenburg, J. Acceptance of Wind Power: An Introduction to Drivers and Solutions. In Alternative Energy and Shale Gas Encyclopedia; Lehr, J.H., Keeley, J., Eds.; John Wiley and Sons Inc.: Hoboken, NJ, USA, 2016; pp. 3-9. 
7. Bird, L.; Lew, D.; Milligan, M.; Carlini, E.M.; Estanqueiro, A.; Flynn, D.; Gomez-lazaro, E.; Holttinen, H.; Menemenlis, N.; Orths, A.; et al. Wind and solar energy curtailment: A review of international experience. Renew. Sustain. Energy Rev. 2016, 65, 577-586. [CrossRef]

8. Brown, T.; Schlachtberger, D.; Kies, A.; Schramm, S.; Greiner, M. Synergies of sector coupling and transmission reinforcement in a cost- optimised, highly renewable European energy system. Energy 2018, 160, 720-739. [CrossRef]

9. Hvelplund, F.; Möller, B.; Sperling, K. Local ownership, smart energy systems and better wind power economy. Energy Strateg. Rev. 2013, 1, 164-170. [CrossRef]

10. Berka, A.L.; Creamer, E. Taking stock of the local impacts of community owned renewable energy: A review and research agenda. Renew. Sustain. Energy Rev. 2018, 82, 3400-3419. [CrossRef]

11. Gorroño-Albizu, L.; Sperling, K.; Djørup, S. The past, present and uncertain future of community energy in Denmark: Critically reviewing and conceptualising citizen ownership. Energy Res. Soc. Sci. 2019, 57, 101231. [CrossRef]

12. Hvelplund, F.; Østergaard, P.A.; Meyer, N.I. Incentives and barriers for wind power expansion and system integration in Denmark. Energy Policy 2017, 107, 573-584. [CrossRef]

13. Plechinger, M. Dansk Vind Slog Rekord i 2019. Available online: https://energiwatch.dk/Energinyt/ Renewables/article11852237.ece (accessed on 11 February 2020).

14. Danish Energy Agency. Energistatistiks 2018; Danish Energy Agency: Copenhagen, Denmark, 2019.

15. Rønne, A.; Nielsen, F.G. Consumer (Co-)Ownership in Renewables in Denmark. In Energy Transition. Financing Consumer Co-ownership in Renewables; Lowitzsch, J., Ed.; Springer Nature Switzerland AG: Cham, Switzerland, 2019; pp. 223-244.

16. Lund, H.; Østergaard, P.A.; Connolly, D.; Mathiesen, B.V. Smart energy and smart energy systems. Energy 2017, 137, 556-565. [CrossRef]

17. Djørup, S.; Thellufsen, J.Z.; Sorknæs, P. The electricity market in a renewable energy system. Energy 2018, 162, 148-157. [CrossRef]

18. Jensen, L.K.; Sperling, K.; Lund, H. Barriers and Recommendations to Innovative Ownership Models for Wind Power. Energies 2018, 11, 2602.

19. Grashof, K. Are auctions likely to deter community wind projects? And would this be problematic? Energy Policy 2019, 125, 20-32. [CrossRef]

20. Aagaard, L. Kunne du Overveje en Vindmølle i Baghaven? Available online: https://www.danskenergi.dk/ nyheder/kunne-du-overveje-vindmolle-baghaven (accessed on 11 January 2020).

21. Gill, S.; Plecas, M.; Kockar, I. Coupling Demand and Distributed Generation to Accelerate Renewable Connections; University of Strathclyde: Glasgow, UK, 2014.

22. Blanco, I.; Guericke, D.; Andersen, A.N.; Madsen, H. Operational planning and bidding for district heating systems with uncertain renewable energy production. Energies 2018, 11, 3310. [CrossRef]

23. Larsen, S.V.; Nielsen, H.; Hansen, A.M.; Lyhne, I.; Clausen, N.-E.; Rudolph, D.; Gorroño-Albizu, L.; Forfang, A.S. Integrating social consequences in EIA of renewable energy projects: 11 recommendations; Aalborg University: Aalborg, Denmark, 2017.

24. IRENA. Renewable Power Generation Costs in 2018; IRENA: Abu Dhabi, United Arab Emirates, 2019.

25. Berka, A.L.; Harnmeijer, J.; Roberts, D.; Phimister, E.; Msika, J. A comparative analysis of the costs of onshore wind energy: Is there a case for community-specific policy support? Energy Policy 2017, 106, $394-403$. [CrossRef]

26. Yildiz, Ö. Financing renewable energy infrastructures via financial citizen participation - The case of Germany. Renew. Energy 2014, 68, 677-685. [CrossRef]

27. Chittum, A.; Østergaard, P.A. How Danish communal heat planning empowers municipalities and benefits individual consumers. Energy Policy 2014, 74, 465-474. [CrossRef]

28. Grøn Energi. Investeringshorisontens indflydelse på fjernvarmesektoren; Grøn Energi: Kolding, Denmark, 2017.

29. Hvide Sande DH. Personal Communication, 2019.

30. Ringkøbing DH. Personal Communication, 2019.

31. Ringkøbing-Skjern Municipality. Personal Communication, 2019.

32. RAH Net. Personal Communication, 2019.

33. Energinet. Personal Communication, 2019.

34. EMD International A/S. Personal Communication, 2019. 
35. Geels, F.W.; Hekkert, M.P.; Jacobsson, S. The dynamics of sustainable innovation journeys. Technol. Anal. Strateg. Manag. 2008, 20, 521-536. [CrossRef]

36. Seyfang, G.; Smith, A. Grassroots innovations for sustainable development: Towards a new research and policy agenda. Env. Polit. 2007, 16, 584-603. [CrossRef]

37. Schot, J.; Geels, F.W. Strategic niche management and sustainable innovation journeys: Theory, findings, research agenda, and policy. Technol. Anal. Strateg. Manag. 2008, 20, 537-554. [CrossRef]

38. Energinet. Energy System Perspective 2035; Energinet: Fredericia, Denmark, 2018.

39. Energinet Transmission System Data. Available online: https://en.energinet.dk/Electricity/Energy-data/ System-data (accessed on 2 January 2020).

40. Evonet Net Kort. Available online: https://sekort.dk/Html5/Index.html?viewer=SE_NetWeb.SE (accessed on 11 January 2020).

41. State of Green The Future Role of DSOs: Europe's Energy System is Turned Upside-Down. Available online: https://stateofgreen.com/en/partners/state-of-green/news/the-future-role-of-dsos-europes-energysystem-is-turned-upside-down/,2017/ (accessed on 11 January 2020).

42. European Commission Expert Group on electricity interconnection targets. Towards a Sustainable and Integrated Europe; European Commission: Brussels, Belgium, 2017.

43. Vittrup, C. Denmark as a Bottom-Up Case. Pitch at the Session: "Decarbonisation of the European Energy System". Available online: https://my.eventbuizz.com/assets/editorImages/1570519706-Workshop1_11501300_-_Carsten_Vittrup.pdf (accessed on 2 January 2020).

44. NOE Net Historie om NOE. Available online: https://www.noe.dk/noe_s_historie (accessed on 2 January 2020).

45. Tornbjerg, J. Vestjyske Elkunder Betaler Overpris for Grøn Omstilling. Available online: https://www. danskenergi.dk/nyheder/vestjyske-elkunder-betaler-overpris-gron-omstilling (accessed on 2 January 2020).

46. Energinet. Ny Viden til Sikker Forsyning. FEI Årsrapport 2018; Energinet: Fredericia, Denmark, 2019.

47. Mathiesen, B.V.; Lund, H.; Hansen, K.; Skov, I.R.; Djørup, S.R.; Nielsen, S.; Sorknæs, P.; Thellufsen, J.Z.; Grundahl, L.; Lund, R.S.; et al. IDA's Energy Vision 2050: A Smart Energy System Strategy for 100\% Renewable Denmark; Aalborg University: Aalborg, Denmark, 2015.

48. Danish District Heating Association. Nyheder. Nærdemokrati Hvide Sande køber vindmøller. Available online: https://www.danskfjernvarme.dk/nyheder/presseklip/arkiv/2016/160812naerdemokrati-hvide-sandekoeber-vindmoeller (accessed on 20 March 2020).

49. Energinet. Systemperspektiv 2035. Baggrundsrapport; Energinet: Fredericia, Denmark, 2018.

50. Energinet International Infrastructure Projects. Available online: https://en.energinet.dk/InfrastructureProjects/Projektliste (accessed on 31 January 2020).

51. Energinet. Personal Communication, 2020.

52. RAH Net Gældende nettariffer og abonnementer. Available online: https://rahnet.dk/priser/nettariffer-ogabonnement/ (accessed on 11 February 2020).

53. Energinet TARIFFER OG GEBYRER. Available online: https://energinet.dk/El/Elmarkedet/Tariffer (accessed on 11 February 2020).

54. Djørup, S. Competing Market Regimes: When and where are supply and demand able to shake hands? An exploration of demand side policies in the Danish energy transition. In Proceedings of the SWEDES Conference, Palermo, Italy, September 30-Octomber 42018.

55. Smartvarme.dk Homepage. Available online: http://smartvarme.dk/ (accessed on 11 January 2020).

56. Danish Government. Energiaftale af 29. June 2018; Danish Government: Copenhagen, Denmark, 2018.

57. Danish Energy Agency Varmepumper-En God Forretning. Available online: https://presse.ens.dk/news/ varmepumper-en-god-forretning-268036 (accessed on 17 January 2020).

58. Danish Energy Agency 15 Værker Får Støtte til Store Varmepumper. Available online: https://presse.ens.dk/ pressreleases/15-vaerker-faar-stoette-til-store-varmepumper-2562721 (accessed on 17 January 2020).

59. Danish Energy Agency Grundbeløbets Ophør og Grundbeløbsindsatsen. Available online: https://ens.dk/ ansvarsomraader/varme/grundbeloebets-ophoer-og-grundbeloebsindsatsen\# (accessed on 17 January 2020).

60. SKAT Bindende Svar. Available online: https://www.rksk.dk/Edoc/Dagsordenspublicering/T1\OkonomiogErhvervsudvalget/2016-08-0909.00/Dagsorden/Referat/Hjemmeside/2016-08-0913.10.32/Attachments/ 1147601-1452497-1.pdf (accessed on 11 January 2020).

61. Energinet Markesdata. Available online: http://osp.energinet.dk/_layouts/Markedsdata/framework/ integrations/markedsdatatemplate.aspx (accessed on 11 January 2020). 
62. Mey, F.; Diesendorf, M. Who owns an energy transition? Strategic action fields and community wind energy in Denmark. Energy Res. Soc. Sci. 2018, 35, 108-117. [CrossRef]

63. Danish Government. Stemmeaftale Mellem Regeringen (Venstre, Liberal Alliance, Det Konservative Folkeparti) og Dansk Folkeparti om ny Støttemodel for Vind og sol i 2018-2019; Danish Government: Copenhagen, Denmark, 2017.

64. Connolly, D.; Lund, H.; Mathiesen, B.V.; Werner, S.; Möller, B.; Persson, U.; Boermans, T.; Trier, D.; Østergaard, P.A.; Nielsen, S. Heat Roadmap Europe: Combining district heating with heat savings to decarbonise the EU energy system. Energy Policy 2014, 65, 475-489. [CrossRef]

65. Energy Transition. Financing Consumer Co-ownership in Renewables, 1st ed.; Lowitzsch, J., Ed.; Palgrave Macmillan: Cham, Switzerland, 2019; ISBN 978-3-319-93517-1.

66. Zeman, J.; Werner, S. District Heating System Ownership Guide; IEE DHCAN project: Watford, UK, 2004.

67. Werner, S. International review of district heating and cooling. Energy 2017, 137, 617-631. [CrossRef]

(C) 2020 by the author. Licensee MDPI, Basel, Switzerland. This article is an open access article distributed under the terms and conditions of the Creative Commons Attribution (CC BY) license (http://creativecommons.org/licenses/by/4.0/). 